\title{
Global GAP Standard Compliance and Smallholder Pineapple Farmers' Access to Export Markets: Implications for Incomes
}

\author{
John K. M. Kuwornu*, Shaibu Mustapha \\ University of Ghana, Legon, Accra, Ghana \\ *jkuwornu@gmail.com
}

\begin{abstract}
This study seeks to determine the effect of compliance with GlobalGAP standards and it implications for access to export market and incomes for smallholder pineapple farmers in the Central region of Ghana. The study was conducted in two pineapple growing districts; Mfantsiman Municipality and Gomoa East district. Primary data were collected through interviews using structured questionnaires. Simple random sampling was used to select 63 pineapple farmers (i.e., 30 Global GAP certified and 33 non-certified farmers from pineapple producer groups in the two districts. Analysis of the marketing channels reveal that market women were the major buyers of pineapple commanding $69.7 \%$ of noncertified farmers produce and $30 \%$ of the produce of the certified (i.e., compliant) farmers. Although $20 \%$ of the certified farmers sold their produce to exporters against $12.1 \%$ for non-certified farmers, it cannot be concluded that farmers' access to the export market has been enhanced by complying with the Global GAP standard. However, all buyers preferred produce from certified farmers to non-certified farmers. On the economic performance of GlobalGAP certified and non-certified pineapple farmers, the empirical results reveal that the Global GAP certified pineapple farmers obtained GHS 15,027.57 for growing one hectare of pineapple while non-certified pineapple farmers made a net average income of GHS 6,256.36. These results imply that the Global GAP certified pineapple farmers obtained 2.4 times more net average income than non-certified pineapple growers. The results of this study have implications for pineapple farmers and policy makers in developing countries.
\end{abstract}

\section{Key words: GlobalGAP Standard, Pineapple farmers, Export market, Incomes, Buyers, Ghana}

\section{Introduction}

Ghana's horticultural export industry is growing faster than above average of the agriculture sub- sector and the country currently relies particularly on horticulture sub-sector, as an engine of economic growth and poverty alleviation (FASDEP II, 2007) and minimization of the country's vulnerability to external price shocks (ADF Appraisal report, 2005). The strategy to diversify agriculture also hinges on the horticultural sub-sector and is expected to play a central role led by the pineapple industry in the country's quest to attain middle -income status by the year 2020 (ADF Appraisal report, 2005). The world market for fresh pineapple has been growing rapidly during the past years. Like other tropical fruits, pineapple is grown predominantly in developing countries, where two thirds of rural people live on small-scale farms of less than two hectares (IFPRI, 2005). According to the Ghana Living Standards Survey (2008), 170, 627 households (2 percent of all households in Ghana) grow pineapple, but not all of them are on commercial basis. Ghana's pineapple production is estimated between 120, 000-150, 000 tons annually. Pineapple exports started in Ghana in the 1980s, increased rapidly after 2000, and then decreased after 2004 due to the slow uptake of the production of the MD2 variety. This fall was accompanied by low prices that have stabilized again since 2007 (Kleemann, 2011). Ghana is the second largest African pineapple exporter to Europe after Côte d'Ivoire and is expected to increase its market share (Natural Resources Institute, 2010; Pay, 2009) and fourth in the world (Jaffee et al., 2011). Ghana's pineapple is almost entirely directed to the European Union.

Fresh pineapple export sub-sector is the most developed of all the non-traditional horticultural export crops in Ghana (Sefa-Dedeh, 2005). It is also enjoying increasing loyalty in the European Union due to its sweetness. However, the inability of smallholder pineapple producers to comply with the ever increasing stringent standards requirements such as Global GAP is having negative impact on the image of the whole agricultural export industry as well as the economy (Revised Ghana Food Safety Action Plan, 2007). Evolution of Global GAP started with the constitution of treaty by World Health Organization which contains regulations on food safety in order to protect international standards concerning animal and plant health in the international trade of agricultural products. The first of the Sanitary and Phytosanitary 
Measures (SPS) is Hazard Analysis and Critical Control Points (HACCP) and the second one is Good Agricultural Practices (GAP), which is applied for fresh fruits and vegetables (International Certification and Auditing Company Limited (CTR), 2007). In accordance with these developments, GAP was first given a start by the US Department of Agriculture (USDA) and the Food and Drugs Administration (FDA) in order to provide food safety in fresh fruit and vegetables. The FAO (Food and Agriculture Organization) also carried out studies on the principles of Good Agricultural Practices during the same period. Finally, bigger retailers of fresh fruit and vegetables from the European Union Member States gathered together to constitute the Euro-Retailer Produce Working Group (EUREP) and prepared the EurepGAP protocol in 1999, covering the principles of Good Agricultural Practices in the growing of fresh fruits and vegetables.

GLOBALGAP was originally established as EUREPGAP in 1997, and in November 2007 the name was changed to GlobalGAP. This is a set of "Good Agricultural Practice" (GAP) standards pertaining to food safety, the environment, animal welfare, worker health and safety established by a consortium of food retailers in Europe as a system of self-appraisal certification by horticultural goods producers (Hobbs, 2010). Intention of GlobalGAP is to change producers' attitudes towards food production by imposing a performance standard with defined criteria to follow in order to render production processes safe through the application of Integrated Farm Insurance Standard (IFA). The GlobalGAP IFA is a pre-farm gate standard and applies to the whole agricultural production process of the certified product, before the plant is in the ground (seed and nursery control points) to non-processed end product (produce handling control points) which combines all agricultural products into a single farm audit (Laforce, 2010). In order to fulfill this commitment, GlobalGAP requirements demands intensive employee training, meticulous record keeping, frequent management reassessments of work methods and results, and annual on-farm inspections of work methods and paper work by external auditors (Richard et al., 2008). A typical checklist of the standard's requirements to smallholders within fruit and vegetables production is stated as follows. Each requirement has a 'major' must, a 'minor' must or a 'recommendation' label which indicate the required level of compliance; major must requires $100 \%$ compliance, minor must requires $95 \%$ compliance and recommendation does not require any minimum percentage of compliance, but must improve when re-inspected (GlobalGAP, 2009).

Certification is carried out by more than 100 independent and accredited certification bodies in more than 80 countries. Failure to respect these requirements will result in GlobalGAP certification being denied or suspended. Although, GlobalGAP is a voluntary standard and business-to-business label which is often not directly visible to consumers, it implementation has become an important prerequisite for accessing the European Market. Smallholder pineapple producers have to comply with these complex and costly requirements in order to remain in business. However, a number of developing Countries including Ghana rely on traditional methods of production and suffer from technical, human resources and financial limitations which prevent them from fulfilling these standards and therefore are excluded from international trade. On the other hand, large-scale commercial producers have found it relatively easy to comply with GlobalGAP as they already have access to the necessary financial, infrastructural and human capacity (Graffham and MacGregor, 2007). GlobalGAP certification comes in four options;

- Option 1: Individual farmers apply for certification under this option.

- Option 2: Is a group certification scheme where smallholder farmers form group and obtain certification together.

- Options 3 and 4 apply to individuals and groups of farmers respectively who are certified standards benchmarked to GlobalGAP.

GlobalGAP standards have become an important determinant of trade competitiveness and a precondition to access the international market. For instance, GlobalGAP certified smallholder fresh pineapples producer groups supported by Market Oriented Agricultural Programme (MOAP) have had continuous export since 2007 leading to increase in earnings of about $45 \%$ between 2008 and 2009. This increase is as a result of both high prices obtained for the pineapple in the international market and increased quantities exported by the groups (MOAP Progress report, 2009). This therefore calls for pragmatic measures in the form of financial investments and capacity building by the state and other national and international organizations to enable smallholder pineapple producers fully translate their comparative advantage into competitive advantage so that they can benefit from the preferential access to international markets through bi-lateral agreements like the African Growth and Opportunity Act (AGOA) of the United States and EU-ACP countries' economic partnership agreements (FASDEP II, 2007). 
Over the years the horticultural sector has received support from national and international organizations with the aim of creating enabling environment to make the sector more competitive and enhance its' access into the international markets. Some of the interventions include the following:

- The Horticulture Export Industry Initiative (HEII) under Agricultural Services Sub-Sector Investment Program (AgSSIP), a Multi-donor initiative led by the World Bank which addressed food safety and quality management issues and construction of pack houses and cold chain facilities.

- USAID’s Trade and Investment Program for a Competitive Export Economy (TIPCEE) is a fiveyear project that seeks to increase the competitiveness of the private sector in agricultural trade. It has two components: export business development and enabling environment which provided assistance for development of supply chain systems such as pineapple, mango, papaya, cashew and Asian vegetables in the form of trainings and the production of training manuals. TIPCEE also collaborated with Ghana Standards Board to draft standards for pineapples, papaya and medicinal plants and obtained GlobalGAP group certifications for farmer groups. The second component involves creation of enabling environment with regard to policy and regulatory issues to boost private sector opportunities.

- African Development Bank's Export Marketing and Quality Awareness Project is a five year program (2006-2011) implemented in four regions in Ghana to address constraints which limit export growth. (ADF Appraisal report, 2005).

- The Millennium Development Authority/Millennium Challenge Corporation (MiDA/MCC) with an agriculture budget of US\$ 241 million aim at among other things enhance export competitiveness in horticultural and other traditional crops.

The Government of Ghana through Ministry of Food and Agriculture (MOFA) developed Food and Agriculture Sector Development Policy (FASDEP II) and one of the policy objectives for implementation is to increase competitiveness and enhance integration into domestic and international markets. However, the role of private standards like GlobalGAP has raised concerns about market access for developing country producers, in particular small and medium producers, who may be capital-constrained at the farm level and may be operating in countries whose lack of adequate infrastructures and services make it too difficult and costly for them to comply with private standards which are often more complex and stringent than that of the public (OECD, 2006ab; Henson and Reardon, 2005). Although these private standards are voluntary and not required by law, they have become de factor mandatory required for doing business (Fulponi, 2006). In Ghana, some of the major pineapple exporters have taken steps toward GlobalGAP certification. However, the standards are rarely designed with the smallholder-based production system in mind-where full traceability and control of field practices are difficult (Danielou and Ravry, 2005). Therefore, the challenge for Ghana is smallholder farmers' certification, which represents the bulk of the pineapple producers. Changing trends in international trade requirements with regard to private standards pose a challenge to participation of smallholders because of the smallscale and scattered nature of production, the low use of inputs, limited access to required technology, and limited access to market information (MoFA, 2010). So far GlobalGAP certified smallholder pineapple producers in Ghana are under option 2 which is a group certification scheme and is on pilot basis through the assistance of international Non-Governmental Organizations (NGOs).

The objectives of the study are fourfold: First, to describe the socioeconomic characteristics of GlobalGAP smallholder pineapple farmers in the study area. Second, to examine the effect GlobalGAP certification on smallholder pineapple farmers' access to the export market. Third, to identify challenges facing smallholder pineapple farmers in complying with the GlobalGAP recommendations. Fourth, to compare economic performance (i.e., income levels) of GlobalGAP certified and non-certified smallholder pineapple farmers in the study area. The results of this study will help to identify success and shortcomings in the implementation of the program before the final evaluation and serve as a source of information for subsequent phase of the program. Thus, the findings will also help:

- Provide valuable insights on the experience and perceptions of smallholder pineapple producers in the study area who have implemented the GlobalGAP option 2 certification. This information will help design programs for replication in other areas.

- Provide information to policy makers and other stakeholders such as MOFA, Federation of Associations of Ghanaian Exporters (FAGE), Ghana Standards Authority (GSA) and Ghana Export Promotion Authority (GEPA) for the development of realistic 'Good Agricultural Practices' (GAPs) manuals suitable for smallholder groups. 
- Contribute to government effort of designing sustainable programs to support the certification of smallholders for export markets.

- Provide information that will assist private standard bodies particularly GlobalGAP to adjust existing standards and develop new ones appropriate for smallholder farmers in Africa.

The rest of study is organized as follows. Section two presents the literature review. Section three provides the methodology. Section four presents the results. Finally, section five presents the conclusions and policy recommendations.

\section{Literature Review}

Smallholder farmers are defined in various ways depending on resource endowment such as land and labor, country and type of commodity being produced. Thus, other terms used interchangeably with 'smallholder' includes 'small-scale', 'resource poor' and 'peasant farmer'. Jaffee (2003) defined smallholder farms as farms with less than 5 hectares of land holding. This definition varies across countries, for instance, in Ethiopia and Kenya, smallholders are farmers with up to 2 acres of beans while in Zambia, smallholders have up to 5 acres of beans land (Okello et al; 2009). In Ghana, smallholder pineapple famers are described as group of small-scale and family producers with less than twenty acres of land with limited access to inputs, mechanical equipment, and training. Although, smallholders represent an important group in pineapple production in Ghana, however, bulk of their production is sold at the local market and also informally sold to large farms (Danielou and Ravry, 2005). Pineapple export plays a significant role in diversification of Ghana's export of which smallholder pineapple producers play key role. This, therefore, makes complying with GlobalGAP standards very difficult because of their characteristics such as low literacy levels, lack of access to land and credit and technical capacity. Danielou and Ravry (2005) identified constraints facing smallholder pineapple producers in Ghana as lack of good roads, cold storage facilities, shipping facilities, reliable energy supplies and telecommunication services, lack of testing facilities, notably for MRLs, as formidable challenges for the sector as whole. They also added that the specific smallholder constraints of low literacy levels, access to land and credit and technical capacity means that there is enormous hurdles that has to be jumped to access high value export markets. They concluded "In fact, the sentiment is that little or nothing is to be gained from upgrading agronomic practices to comply with standards, unless the infrastructures and services to the sector were likewise upgraded to enable exporters to meet increasingly competitive commercial requirements" (Danielou and Ravry, 2005).

There are limited studies that have looked at constraints influencing compliance of GlobalGAP standards. Most studies on food safety standards centered on Hazard Analysis and Critical Control Points (HACCP) and Sanitary and Phytosanitary Standards (SPS); for example, Charlotte and Fairman 2003). Also, to the best of our knowledge, with exception of Okello (2005) and Graffham \& MacGregor (2007), most studies focused on farmers in developed countries and in the Middle East (e.g., Charlotte and Fairman, 2003). The most widely cited constraints hindering compliance with GlobalGAP standards is the additional cost that farmers have to incur to adjust to the GlobalGAP recommendations. The question is; how significant is the cost of GlobalGAP compliance? Asfaw et al. (2008) in their article Food-safety standards: A catalyst for the winners - a barrier for the losers? The case of GlobalGAP in horticultural export from Kenya published in agrifoodstandards.net showed that the costs of compliance with GlobalGAP standards for small-scale export vegetable producers operating under option two certification scheme is about 36,600 KSh per individual member of the group and about 8,390 KSh per group member by the exporters and/or donors. The investment cost borne by individual farmers accounts for approximately 30 per cent of their total annual crop income. A Group supplier membership costs $€ 2550$ annually (GlobalGAP, 2011). The bulk of costs incurred by individual farmers (about 90 per cent) are for investment in infrastructure and equipment that they must have as a pre-condition for implementing standards. These represent the nonrecurring costs and are primarily meant for record keeping and in support of internal self-inspection (e.g. office construction and furniture), crop protection (e.g. chemical store, pesticide disposal pit), worker safety, health and welfare (e.g. waste disposal pit, toilet and bathroom) and product handling (e.g. grading shed and charcoal cooler).

Aloui and Kenny (2005) revealed that compliance with GlobalGAP standards poses several technical and financial problems for Moroccan producers and exporters. They found that, for a medium-sized tomato farm of $10 \mathrm{ha}$, the cost of implementing the GlobalGAP standard is estimated at $8 \%$ of the total accumulated farm gate costs. After post harvest, transport, and marketing costs are added, compliance 
costs represent $3 \%$ of the total cost. Recurring costs which include; training, monitoring and surveillance, and certification are estimated at $2 \%$ of the farm gate costs. Wechter and Grethe (2006) in a study on GlobalGAP adoption by mango exporters in Australia noted that smallholders run the risk of being excluded from EU market if they are not supported to adopt GlobalGAP standards because of cost involved. Further, Graffham, (2006) in his study in Zambia noted that high cost of GlobalGAP certification charged by certifiers as well as other recurring costs such as audit expenses, training and expensive pesticides act as barriers to compliance. Minot and Ngigi (2004) attributed limited access to credit, technical information lack of rural infrastructure, high transportation cost and insufficient support services as constraints that limit smallholder farmer's ability to adopt GlobalGAP. Farm and household specific characteristics have been cited as major barriers to compliance with food safety standards. For instance, Charlotte and Fairman, (2003) identified the major barriers as; lack of knowledge throughout the compliance decision process, lack of support services, lack of money to cater for the costs of compliance, and lack of information. Market access refers to whether or not consumers and sellers are well-informed about demand/supply situations and how easily each party can take advantage of the available opportunities (Killick, et al., 2000). Thus, the farmer is said to have access to market when he/she is able to sell all produce destined for the market. Dynamics surrounding modern day Global value chain requirements has become crucial in understanding smallholder farmers' constraints in relation to market access. These constraints act as barriers to market which the smallholder farmers have to surmount in order to have access to domestic, regional and international markets. In Sub-Saharan Africa, access to markets does not guarantee successful integration into international trade. This is because the region faces the lowest tariff barriers due to bilateral and multilateral agreements which give it preferential access to international markets, but this has not halted its marginalization.

There are many factors which determine market accessibility in smallholder farming. Van Roekel et al., (2002) mentioned consumer demand in terms of taste, health, safety and sustainability as requirements for market access. In South Africa, the National Department of Agriculture Directorate: Marketing (2002) findings indicated that smallholder fresh produce farmers are confronted with lack of proper market outlets because of long distance and/ or lack of transport which deprived these resource poor farmers of formal market access. Most studies concluded that implementation of certification requirements can contribute to enhancing producers' market access and visibility situation and reduced uncertainty about market conditions (Raynolds and Ngcwangu, 2010; Bolwig et al., 2009), as well as implementing better farming practice and gaining increased access to credit (Borot de Battisti et al., 2009). Poor infrastructure increases marketing cost for smallholder farmers in Sub-Saharan Africa. Transport costs alone add 15\%$20 \%$ to the price of Sub-Saharan Africa's exports (Aschenaki, 2004). This is consistent with the assertion by Diao and Hazell (2003) that smallholder farmers in Sub-Saharan Africa receive $10 \%-20 \%$ of the export price of their produce, with the remainder being lost to transport and market costs. Technical and institutional constraints such as production of poor quality products and tariff barriers and non-tariff barriers has been noted to be responsible for failure to guarantee market access (e.g., Bahiigwa, 2006). Non-tariff barriers in the form of technical standards and sanitary and phytosanitary (SPS) measures such as GlobalGAP pose a greater threat than most barriers thus limiting farmers from developing countries from exporting their products to developed countries (Orden et al., 2004) .

In Ghana, one of the prominent constraints identified in the agricultural is lack of market access resulting from increasing levels and multiplicity of standards (food safety and phytosanitary) and stringent and continually changing SPS requirements of importing countries in international trade, especially of high value agricultural export commodities (FASDEP II, 2007). A survey conducted by Asfaw et al, (2008) on Kenyan horticultural exports and published in fresh perspective (agristandstandards.net) showed that producers perceived that adoption of GlobalGAP would assure them of market, higher prices, timely payment by exporters, increased quality of production and reduced the amount of buyer rejection. Also, this study revealed that adoption of GlobalGAP improved bargaining power of farmers which enabled them to switch more easily from one buyer to another. Variety produced also influences market accessibility of smallholder farmers into the export market. In Ghana, for example, prior to the introduction of MD2 pineapple variety, about $40 \%$ of pineapple exports were from smallholder farmers (MoFA, 2010). Most of the studies reviewed showed positive impact of private standards on net income and regarded higher prices as the main factor influencing an increased net income for producers. For instance, this apply to organic cocoa in tropical Africa (Gibbon et al., 2009), organic bananas in Peru (Fort and Ruben, 2008) and smallholder organic coffee in Uganda (Bolwig et al., 2009). Other studies also regarded increased premiums as an important component of increases in producer profitability, especially in Fairtrade and in Organic coffee (e.g., Bolwig and Odeke, 2007), indicating that differences in 
yield and quality might contribute to this increased profitability (Sexsmith and Potts, 2009). On difficulties of quantifying impact of private standards on profitability, several studies (e.g., Sexsmith and Potts, 2009) point to the role of donors in bearing the costs distorts the assessment of the profitability at the producer level.

In Organic and GlobalGAP certification, there is also an option for the certification holder to be a different entity than the producer. Exporters or NGOs can pay for the certificate and thus shield the producer from some of the costs or risks associated with the certification program. However, this can also mean that the benefits related to profitability or market access are less transparent or directly applicable to the farmers involved. One study that specifically compared income levels between GlobalGAP certified and uncertified farmers is the one carried out by Bayramoglu et al., (2010) in Turkey. They focused on the benefits of good agricultural practices to producers and attempts to test whether a difference exists between the incomes of farmers carrying out production activities in compliance with GlobalGAP standards and farmers who produce with no certification, in the context of tomato production in greenhouses. The study showed that certified farmers have lower productivity, spent less and obtained a higher level of net income. They also realized that the GlobalGAP certified tomato producers obtained a net income of $\$ 9,349.9$ from growing one hectare of tomatoes while the uncertified tomato producers got a net income of $\$ 3,287.7$ representing 2.8 times more than the uncertified tomato growers. This study examines the effect GlobalGAP certification on access to export markets by small holder pineapple farmers in Ghana, and how this impacted on their net pineapple farm incomes. The study also examines the constraints facing these pineapple farmers regarding compliance with the GlobalGAP certification.

\section{Methodology}

Economic theory underpinning compliance with the GlobalGAP standards: This study uses economic theory of farm production to explain the decision of farmers to adopt and implement new technology in his/her farm business. In general, the economic theory of the farm business is based on the concept of marginal analysis (i.e. incremental or additional changes in either revenues or costs as farmer makes changes in farm production). Economic decisions made by the farmer therefore are based on marginal changes in costs and revenues with the aim to maximize profits or net revenues. Hence the farmer may adopt and implement GlobalGAP recommendations if the expected marginal change in revenue exceeds the marginal costs. It is assumed that the farmer will maximize his/her profit if he/she adopts GlobalGAP standards because it will enhance his access to export market and receive price premium such that revenue offset the costs of production and compliance to the standards. In Ghana, farming in general and horticultural production in particular is confronted with constraints which make it a risky venture. Risks generally increase with the increase in expected income (Kuwornu et al., 2009). The farmer can be conceptualize as having utility or satisfaction for income or wealth and depending on the risk attitude of the farmer he/she can be described either as risk- averse, risk neutral or risk lover. To make better use of economic theory of farm production, risk has to be introduced into the theoretical framework of this study. It is believed that most farmers are risk averse because they are cautious in accepting new technologies or making additional investments in their farm enterprise especially if these changes will have direct effect on their income and livelihood. The degree of farmer's risk aversion depends on his socioeconomic characteristics as well as availability of technical and institutional support systems like infrastructure, credit, market information, contract farming etc. Consequently, the farmer makes a decision to adopt new technologies like GlobalGAP standard recommendations if risk is reduced. Risk aversion decreases with increase in support systems as well as increase in assurances in the form of market access, price premiums and income which help to relax constraints facing the farmer.

Data Analysis Techniques Used: Descriptive and profitability techniques were used to analyze the data with the aid of Statistical Product for Services Solutions (SPSS) and Microsoft Excel.

Methods of Analysis: Objective one which describes the socioeconomic and farming characteristics of certified and non certified farmer groups were captured using data obtained from the questionnaires. The variables captured included sex, age of household heads, level of education, marital status, farming experience, land size membership of farmer groups, and levels of awareness about GlobalGAP requirements among the certified farmers. Data collected were analyzed and results presented as percentages. Objective two was to analyze the role of GlobalGAP certification in enhancing smallholder pineapple farmers' access into the export. This was achieved by comparing marketing channels used by the two farmer groups (i.e., certified and non-certified farmers) and presented as percentages. There are 
four possible buyers of pineapple in Ghana: exporters, market women, processors and brokers/agents. Constraints hindering non-certified farmers and that faced by certified farmers in maintaining their certification were analyzed under objective three. Non-certified farmers were asked to list constraints that hindered their compliant with GlobalGAP certification while certified farmers listed constraints they encounter in maintaining their certification status. These were presented as percentages. Objective four which was to compare income levels of certified and non certified farmer groups was achieved by using economic indicators; average production costs, selling price, total yield, average revenue and average net income of pineapple production. Total yields were expressed on a per hectare basis. The average net income was calculated as average revenue minus the average production costs. Both direct and fixed expenses were used in estimating the production costs, therefore the net income calculated based on the unit area (i.e., one hectare) shows the economic profit of the farming activities (Kiral et al., 1999).

The Study Area: The study was conducted in Mfantsiman municipality and Gomoa East district all in the Central region of Ghana. Mfantsiman municipality has a total land area of approximately $612 \mathrm{sq} . \mathrm{km}$. $(61,200 \mathrm{ha})$ with available arable land for agriculture of 280,000 ha and lies within latitudes $5^{\circ} .07^{\prime}$ to $5^{\circ} .20^{\prime}$ north of the Equator and between longitudes $0^{\circ} .44^{\prime}$ to $1^{\circ} .11^{\prime}$ west of Greenwich meridian. The municipality has a total population of 211,916 . It has two types of vegetation; the coastal shrub and the flood plains. Temperature range between 24 to $28^{\circ} \mathrm{C}$ with relative humidity about $70 \%$ with a bimodal rainfall. The area is characterized by savannah ochrosols. Soils along river banks and irrigated sites are loose clay. The municipality is bounded to the East by Gomoa East district. Gomoa East District was among the twenty seven districts created in 2008 with its capital situated at Afransi. The district is located in the south-eastern part of the Central Region and situated between latitudes 5014' North and 5035' North and longitudes 0022 West and 0054' West. The district benefitted from the MiDA program under the Millennium Challenge Account (MCA) because of it potential in pineapple production.

Sampling and Data: This study was conducted in two pineapple growing districts in the Central Region of Ghana namely Mfantsiman Municipality and Gomoa East district. Primary data were collected through interviews using structured questionnaires. Simple random sampling was used to select 63 pineapple farmers (i.e., 30 GlobalGAP certified and 33 non-certified farmers from pineapple producers groups in the two districts.

\section{Results and Discussion}

Socioeconomic and Farm characteristics: Average age of certified and non-certified farmers was found to be about 51 and 41 years respectively with the youngest farmer being 29 years old. It worth noting that more than one farmer of the certified group was 70 years of age, while the non-certified group has the youngest farmer being 29 and the oldest being 53 years old. On the contrary, it was expected that certified farmers would be younger than the non-certified farmers since they might be more open to new technologies or practices and therefore adopt GlobalGAP certification (D'Souza et al., 1993). Further, the data indicated that there were not many variations in farming experience. The data revealed that certified farmers have on average 19.9 years of experience in farming and 11.3 years in pineapple production while the non-certified farmers have 18.5 years in farming and 12.2 years in pineapple production. However, it was expected that certified farmers will have long-term experience in growing pineapple than the non -certified ones. Next, farmers across the two groups had some education, mostly up to basic level (Primary to MSLC/JHS) education although some did not have any education at all. With regard to secondary and tertiary education, $20 \%$ of certified farmers had secondary education against $9.1 \%$ for non-certified farmers. Also, $20 \%$ of certified farmers attained tertiary education; while none of noncertified farmers had tertiary education. Thus, levels of education seem to influence farmers' decision to adopt certification. In addition, the marital status is classified into three categories namely: single, married and divorced. Most household head respondents were married across the two groups; $86.7 \%$ and 93.1\% for certified and non-certified farmers respectively while the rest were either single or divorced. Moreover, regarding gender of the respondents, more males are involved in pineapple farming than females in Central Region of Ghana. This result is expected because of the role of men as head of the household. In most cases female farmers are classified as household head when they are not married, divorced or widowed. The data showed that males constitute $66.7 \%$ of the certified farmers and $84.8 \%$ of the non-certified respondents while female farmers were $13.3 \%$ and $15.2 \%$ respectively.

The data suggest that more than half (53.3\%) of the certified farmers are farming under contract while non-certified farmers had no contract with an intermediary in the marketing channel. Contract farming 
reduces risk because it ensures marketing of produce and guarantees a steady source of supply to the contractor. This finding is consistent with Murithi et al., (2008) that compliance with GlobalGAP standards promotes contract farming especially with exporters. Apart from producing pineapple, $23.3 \%$ and $54.5 \%$ of certified and non-certified farmers respectively are involved in off- farm income generating activities. This shows that non-certified farmers depend more on off- farm income generating activities than certified farmer group. Access to extension services by farmers increases their chances to comply with GlobalGAP standards since it gives them the opportunity to receive information and training. All the respondents had access to extension services mostly from government extension agents. In this respect, certified farmers received the highest quarterly visits $(76.7 \%)$ whiles the highest visit among noncertified farmers was monthly visits (63.6\%). It is expected that farmers with the shortest frequency of visits would be more informed than their counterparts and hence have the highest likelihood of adopting new technology. However, certified farmers had longer frequency of visits which implies that the shorter frequency of visits by the extension agents did not influence adoption of technology, since the certified farmers who adopted GlobalGAP standard were visited less frequently. A comparison of the mean values of total land owned and rented by the groups indicates that certified farmers have 36.1 acres (14.4 hectares) and non-certified farmers have 17.7 acres ( 7.08 hectares). Certified farmers and non-certified farmers cultivated on average 3.8 acres (1.52 hectares) and 4.09 acres (1.63 hectares) respectively indicating all farmers in the study area can be classified as smallholders because cultivated lands are below 5 hectares (e.g., Jafee, 2003; Danielou and Ravry, 2005, Okello et al., 2009).

Level of Awareness of Aspects of GlobalGAP Requirements among Certified Farmers: Figure 1 below shows the level of awareness regarding various aspects of GlobalGAP requirement among the certified farmers in the study area. Majority of the farmers (more than 50\%) are aware of the various aspects of the GlobalGAP requirements with all the respondents $(100 \%)$ aware of traceability, record keeping and internal inspection, and harvesting while only $43.3 \%$ of the respondent were aware of irrigation and fertigation. The low level of awareness about irrigation and fertigation could be because the farmers do not practice irrigation.

\section{Figure 1: Level of Awareness of Aspects of GlobalGAP Requirements among Certified Farmers}

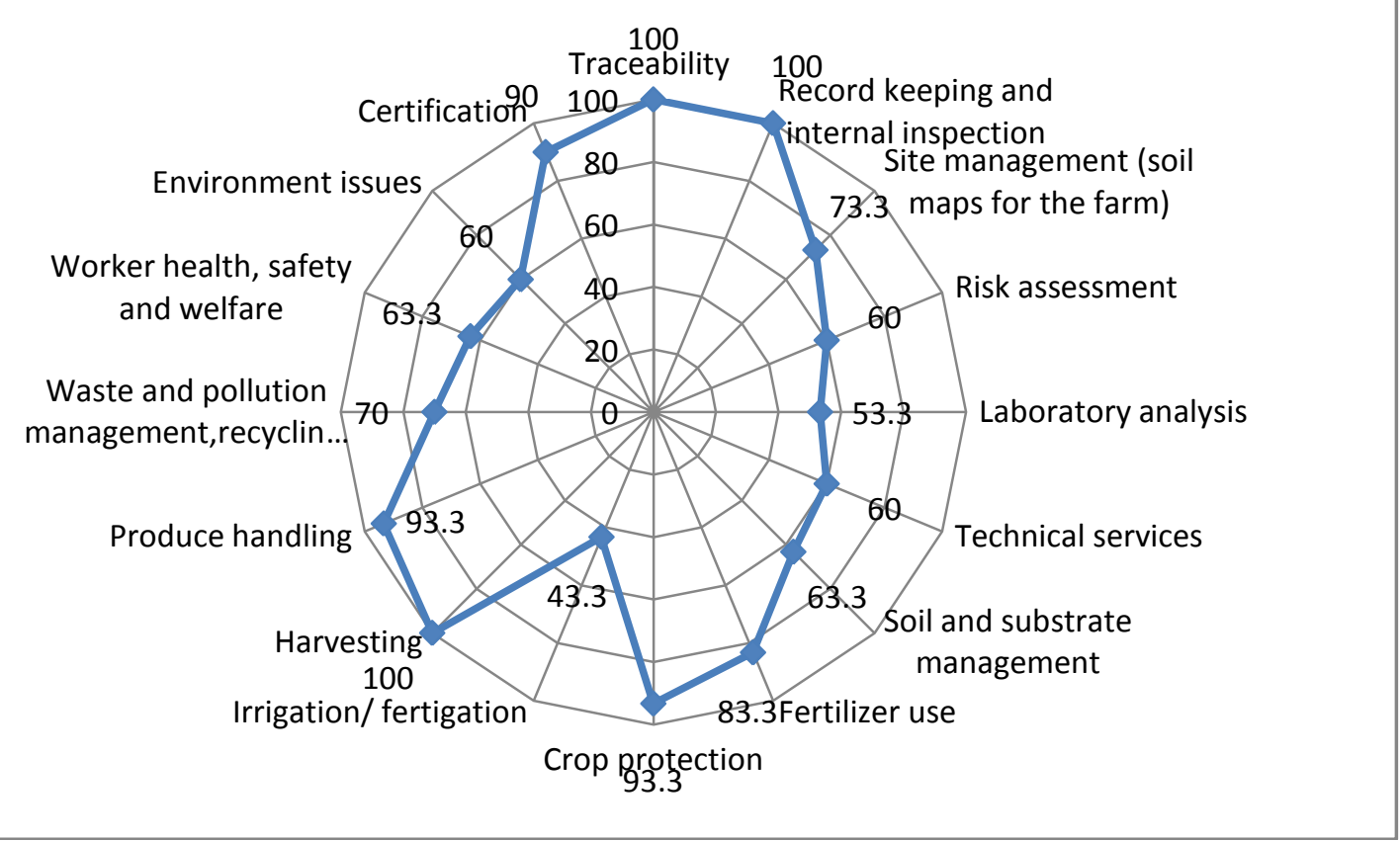

Marketing Channel Analysis: Analysis of marketing channel identified transactions of the GlobalGAP certified and the non-certified pineapple farmers. Basically smallholder pineapple producers have three options selling to market women, processors and exporters. Market women buy from farmers and in turn supply to supermarkets in urban centers, small food stores, open market traders and sometimes to street vendors/ hawkers who seldom buy from farmers directly. On the other hand, processors buy from farmers often through contract farming so as to ensure steady supply of pineapple or through brokers/agents. Exporters, unlike market women and sometimes as processors are selective in their choice of producers from whom they buy their pineapple because of the need to satisfy food safety 
standards such as GlobalGAP standards demanded by importing countries. The expectation is that adoption of GlobalGAP by pineapple farmers would assure them of ready market, higher prices and timely payment by exporters. Table 1 shows that $20 \%$ of the certified and $12.1 \%$ of the non-certified farmers reported selling to exporters. Though a higher percentage, the difference between $20 \%$ for certified farmers and that of the non-certified farmers $(12.1 \%)$ is not very large, this is somewhat below expectation. Around $17 \%$ of the certified farmers reported selling to processors while non-certified farmers did not sell to processors at all. Majority of non-certified farmers' (69.7\%) produce were bought by market women while $30 \%$ of the certified farmers reported selling to market women. Interestingly, $33.3 \%$ of certified farmers reported selling to a combination of the three buyers as against 18.2 by noncertified farmer groups. This is indicative of the fact that all the buyers prefer buying from certified farmers than from non-certified farmers apart from the market women.

Table 1: Description of the Marketing Channel of Pineapple Produced by Certified and Non Certified Farmers

\begin{tabular}{lll}
\hline Market Channels & Producers & \\
\hline Solely Exporters & Certified (\%) & Non-certified (\%) \\
Solely processors & 20.0 & 12.1 \\
Solely market women & 16.7 & 0 \\
Combination of the three & 30.0 & 69.7 \\
\hline
\end{tabular}

Challenges Facing Farmers in Complying with the GlobalGAP Recommendations: Table 2 presents results on constraints hindering non-Certified farmers to comply with GlobalGAP standards while Table 3 shows results on constraints encountered by certified farmers in maintaining the GlobalGAP standard. Table 2 shows that all the non-certified farmers reported lack of money to construct required facilities as a major constraint. The required facilities include equipment and infrastructure such as storage facilities for chemicals, tools and toilet facilities. Two other major constraints reported were lack of money to pay the external auditor, and lack of price difference between pineapple from certified farms and noncertified farms. Regarding price difference, expectation of the farmers was that they will receive high price for their produce when they comply. However, they observed that there were no significant differences in prices per kilogram received by certified farmers and prices received by them (i.e., the noncertified farmers). About 57\% also reported lack of money to pay and join the certified groups as a major constraint. About 27\% complained of lack of time to attend trainings because training periods conflict with their farming activities. The above observations agree with Graffham's study in Zambia where he noted high cost charged by certifiers, audit expenses, training and expensive pesticides as barriers to compliance (Graffham, 2006). Table 3 presents results on constraints certified farmers encounter in maintaining GlobalGAP standards. Difficulties involve in keeping to the rules and procedures were reported by $66.7 \%$ of the farmers as a major constraint. This was followed by difficulties involved in acquiring recommended chemicals from approved sources which was reported by $50 \%$ of the farmers. About $33 \%$ of the farmers mentioned keeping of records and lack of money to pay for services of external auditors as a major constraint. Other constraints mentioned by about $16 \%$ of the farmers were monitoring of farm workers, low price of produce and group dynamics.

Table 2: Percentage of Non-certified Farmers Reporting Constraints Hindering Complying with GlobalGAP standards ${ }^{1}$

\begin{tabular}{lc}
\hline Constraints & $\mathbf{N}=\mathbf{3 3}$ \\
\hline Lack of money to construct required facilities & 100 \\
Lack of money to pay to join certified group & 57.6 \\
Lack of money to pay for external auditor & 60.6 \\
No price difference in pineapple from certified and non-certified farms & 60.6 \\
Lack of time for training & 27.3 \\
\hline
\end{tabular}

\footnotetext{
${ }^{1}$ Please note that the results of percentages in each of Tables 2 and 3 will add up to more than $100 \%$ because the farmers responded to multiple items.
} 
Table 3: Percentage of Certified Farmers Reporting Constraints Encountered in Maintaining GlobalGAP Certification

\begin{tabular}{ll}
\hline \multicolumn{1}{c}{$\mathbf{N}=\mathbf{3 0}$} & $\mathbf{\%}$ \\
\hline Proper keeping and storage of past records & 33.3 \\
Difficulty in raising money to pay for external auditors & 33.3 \\
Difficulty in acquiring recommended chemicals from approved source & 50.0 \\
Regular monitoring of farm workers & 16.67 \\
Difficulty in keeping to the rules and procedures consistently & 66.7 \\
Low prices of produce & 16.67 \\
Group dynamics & 16.67 \\
\hline
\end{tabular}

In general, the constraints identified in Tables 2 and 3 are consistent with previous studies (e.g., Minot and Ngigi, 2004; Charlotte and Fairman, 2003; Danielou and Ravry, 2005; Graffham, 2006).

Comparing Economic Performances of Producer Groups: Table 4 shows that the average yield of the farmer groups under study was established to be higher for the certified pineapple farmers, at a value of $69,763.75 \mathrm{~kg} / \mathrm{ha}$, compared to the non-certified group $(46,347.80 \mathrm{~kg} / \mathrm{ha})$. Thus, the difference between the two farmer groups in terms of yield was found to be $51 \%$. There was, however, not much difference between the farmer groups in terms of sales price. The difference is only $5 \%$ higher for the certified farmers. On the other hand, there is a $58 \%$ difference between the average revenue of the farmer groups. Thus, certified farmers obtained 58\% more average revenue than the non-certified farmers. Production cost for the certified farmers was found to be $13 \%$ more than that of non-certified farmer group. Further, with respect to average net income, the GlobalGAP certified pineapple farmers obtained GHS 15,027.57 for growing one hectare of pineapple while non-certified pineapple farmers made a net average income of GHS 6,256.36. This implies that the GlobalGAP certified pineapple farmers obtained 2.4 times more net average income than non-certified pineapple growers. Following from the differences in prices and net average income, the high net income obtained by certified farmers was mainly due to increased output rather than price premium. The increased income resulting from the GlobalGAP certification of the pineapple farmers is consistent with previous findings (e.g., Gibbons et al., 2009; Fort and Reuben, 2008; Bolwig et al., 2009; Sexsmith and Pott, 2009).

Table 4: Economic Performance of GlobalGAP Certified and Non-Certified Pineapple Farmers ${ }^{2}$

\begin{tabular}{|c|c|c|c|c|c|}
\hline \multicolumn{3}{|c|}{ Certified farmers } & \multicolumn{2}{|c|}{ Non-Certified farmers } & \multirow{2}{*}{$\begin{array}{l}\text { Variable of Certified } \\
\text { farmers / Variable of Non- } \\
\text { Certified farmers x100 }\end{array}$} \\
\hline Indicators & Mean & $\begin{array}{l}\text { Standard } \\
\text { Deviation }\end{array}$ & Mean & $\begin{array}{l}\text { Standard } \\
\text { Deviation }\end{array}$ & \\
\hline Average yield (Kg/Ha) & $69,763.75$ & $8,436.5376$ & $46,347.80$ & $3,972.695$ & 151 \\
\hline Selling price (GHS/Kg) & 0.398 & 0.0703881 & 0.378 & 0.048461 & 105 \\
\hline Average Revenue (GHS/Ha) & $27,643.49$ & $5,461.85$ & $17,530.60$ & $2,601.639$ & 158 \\
\hline $\begin{array}{l}\text { Average Production cost } \\
\text { (GHS/Ha) }\end{array}$ & $13,102.17$ & $1,668.22$ & $11,554.55$ & $1,147.10$ & 113 \\
\hline $\begin{array}{l}\text { Average } \\
\text { (GHS/Ha) }\end{array}$ Net income & $15,027.57$ & $5,955.35$ & $6,256.36$ & $2,659.064$ & 240 \\
\hline
\end{tabular}

\section{Conclusion and Recommendations}

This study seeks to examine the effect of compliance with GlobalGAP standards and it implications for access to export market and incomes for smallholder pineapple farmers in the Central region of Ghana. The study was conducted in two pineapple growing districts in the Central Region of Ghana namely; Mfantsiman Municipality and Gomoa East district. Primary data were collected through interviews using structured questionnaires. Simple random sampling was used to select 63 pineapple farmers (i.e., 30 GlobalGAP certified farmers and 33 non-certified from pineapple producers groups in the two districts. The descriptive statistics show that socioeconomic and farm characteristics of the farmers such as level of education and contract farming influenced adoption of GlobalGAP standard while age, gender, off-farm income generating activities and frequency of extension contacts did not influence compliance. Certified farmers and non-certified farmers cultivated on average 3.8 acres (1.52 hectares) and 4.09 acres (1.63 hectares) respectively indicating that pineapple farmers in the study area are generally smallholders. On

\footnotetext{
${ }^{2}$ Please note that the average net income reported here is the same as the average profit per hectare of pineapple production.
} 
awareness of GlobalGAP standard, all certified farmers were aware of GlobalGAP standard but levels of awareness in the various aspects of the GlobalGAP protocols vary. Traceability, record keeping and internal inspection and harvesting recorded the highest (100\%) and only about $43 \%$ of the certified farmers were aware of irrigation and fertigation items in the GlobalGAP protocols. Analysis of the marketing channels reveal that market women were the major buyers of pineapple commanding $69.7 \%$ of non-certified farmers produce and $30 \%$ of the compliant farmers. Although $20 \%$ of the certified farmers sold their produce to exporters against $12.1 \%$ for non-certified farmers, it cannot be concluded that farmers' access into the export market has been enhanced by complying with the GlobalGAP standard. However, all buyers preferred produce from certified farmers to non-certified farmers.

Lack of money to construct required facilities, pay for certification and external auditor, and lack of price difference were identified as major constraints hindering compliance of non-certified farmers. Major constraints encountered in maintaining GlobalGAP standard among the compliant farmers were difficulties involve in keeping to the rules and procedures and difficulties involved in acquiring recommended chemicals from approved sources. Other constraints pointed out by farmers included keeping of records, lack of money to pay for the services of external auditors, monitoring of farm workers, low price of produce and group dynamics. On the economic performance of GlobalGAP certified and noncertified pineapple farmers, the results reveal that the average yield of the farmer groups under study was established to be higher for the certified pineapple farmers, at a value of $69,763.75 \mathrm{~kg} / \mathrm{ha}$, compared to the non-certified group $(46,347.80 \mathrm{~kg} / \mathrm{ha})$. Thus, the difference between the two farmer groups in terms of yield was found to be $51 \%$. There was, however, not much difference between the farmer groups in terms of sales price. The difference is only $5 \%$ higher for the certified farmers. On the other hand, there is a $58 \%$ difference between the average revenue of the farmer groups. Thus certified farmers obtained 58\% more average revenue than the non-certified farmers. Production cost for the certified farmers was found to be $13 \%$ more than that of non-certified farmer group. Further, with respect to average net income, the GlobalGAP certified pineapple farmers obtained GHS 15,027.57 for growing one hectare of pineapple while non-certified pineapple farmers made a net average income of GHS 6,256.36. This implies that the GlobalGAP certified pineapple farmers obtained 2.4 times more net average income than non-certified pineapple growers. Following from the differences in prices and net average income, the high net income obtained by certified farmers was mainly due to increased output rather than price premium.

GlobalGAP certification will not go away and will continue to be a requirement for accessing the lucrative export market. There is therefore the need to support farmers reducing the cost of compliance, so as to make the process of compliance easier and affordable to smallholder farmers. The study provides the following recommendations. First, the Government of Ghana through Ministry of Trade and Industry; and Ministry of Foreign Affairs and Regional integration should help improve access to markets in the ECOWAS region where standards are less stringent. Second, the Government of Ghana should support the National Horticultural Task Force to speed up development of GhanaGAP as it will qualify and harmonize different standards around the globe in order to facilitate access to the export markets by Ghanaian horticultural exporters. Third, the Government of Ghana should intensify the assistance she provides in building capacity of extension agents to provide market information and link pineapple producers to buyers. Fourth, the profitability of pineapple production depends on price premium. Therefore, there is the need for a policy that will introduce different price structures for certified and non- certified produce so as to encourage compliance.

\section{References}

African Development Fund (ADF). (2005). Ghana Export Marketing and Quality Awareness Project (EMQAP), Appraisal Report. Agricultural and Rural Development Department (OCAR).

Aloui, O. \& Kenny, L. (2005). The Cost of Compliance with SPS standards for Moroccan Exports: A case Study. The International Bank for Reconstruction and Development / the World Bank.

Asfaw, S., Mithöfer, D. \& Waibel, H. (2008). Food-safety standards: A catalyst for the winners - a barrier for the losers? The case of GlobalGAP in horticultural export from Kenya. Fresh perspective, Agrfood standards, and pro-poor growth in Africa.

Aschenaki, B. (2004). Transport Costs in Ethiopia: An Impediment to Exports. Background Study for the World Bank's FY04 Country Economic Memorandum for Ethiopia. Washington, DC. [http://siteresources. worldbank.org/INTETHIOPIA/Resources/PREM/Ethiopia-Transport_CostFinal.pdf]. 
Bahiigwa, G. (2006). Access of Eastern African Farmers to Domestic and International Markets: Opportunities and Constraints. Invited paper prepared for presentation at the International Association of Agricultural Economists Conference, August 12-18, 2006, Gold Coast, Australia. 28.

Bolwig, S. \& Odeke, M. (2007). Household food security effects of certified organic export production in tropical Africa. Danish Institute for International Studies, Copenhagen.

Bolwig, S., Gibbon, P. \& Jones, S. (2009). The Economics of Smallholder Organic Contract Farming in Tropical Africa. World Development, 37(6), 1094-1104.

Borot-de-Battisti, A., MacGregor, J. \& Graffham, A. (2009). Standard bearers: Horticultural exports and private standards in Africa. International Institute for Environment and Development, London.

Bayramoglu, K., Gundogmus, E. \& Tatlidil, F. F. (2010). The impact of EurepGAP requirements on farm income from greenhouse tomatoes in Turkey. African Journal of Agricultural Research, 5(5), 348355.

Charlotte, Y. \& Fairman, R. (2003). Factors affecting food safety compliance within small and mediumsized enterprises: Implications for regulatory and enforcement strategies. Centre for Risk Management, King's College London, London WC2 2LS, UK.

Danielou, M. \& Ravry, C. (2005). The Rise of Ghana's Pineapple Industry: From Successful Takeoff to Sustainable Expansion. Africa Region Working Paper 93, World Bank Washington DC.

Diao, X. \& Hazell, P. (2003). Africa: Exploring Market Opportunities for African Smallholders. 2020 Africa Conference Brief 6. International Food Policy Research Institute, Washington, DC.[http://www.ifpri.org/pubs/ib/ib22.pdf].

D’Souza, G., Cyphers, D. \& Phipps, T. (1993). Factors Affecting the Adoption of Sustainable Agricultural Practices. Agricultural and Resource Economics Review, 22(2), 159-165.

Food and Agriculture Sector Development Policy II. (2007). Ministry of Food and Agriculture, Ghana.

Fort, R. \& Ruben, R. (2008). The impact of fair trade on banana producers in Northern Peru, in Ruben, R. (ed.) The impact of Fair Trade. Academic Publishers, Wageningen, Chapter 2.

Fulponi, L. (2006). Private voluntary standards in the food system: The perspective of major food retailers in OECD countries. Food Policy, 31(1), 1-13.

Ghana Statistical Service. (2008). Ghana Living Standards Survey. Fifth Round (GLSS5),CD-Rom, September 2008.

Gibbon, P., Lin, Y. \& Jones, S. (2009). Revenue effects of participation in smallholder organic cocoa production in tropical Africa, 06. Danish Institute for International Studies (DIIS). Copenhagen.

GlobalGAP. (2009). http://www.globalgap.org

GlobalGAP. (2011). http://www.globalgap.org/cms/frontcontent.php?idart=2564.Accessed 15- 08-2011.

Graffham, A. (2006). EU legal requirements for imports of fruits and vegetables (a suppliers guide), Fresh Insights no. 1, DFID/IIED/NRI, www.agrifoodstandards.org. Accessed on 23-11-2011.

Graffham, A. \& MacGregor, J. (2007). Impact of EurepGAP on small-scale vegetable growers in Zambia, Fresh Insights, 5.

Henson, S. \& Reardon, T. (2005). Private agri-food standards: Implications for food policy and the agrifood system. Food Policy, 30(3), 241-253.

Hobbs, J. E. (2010). Public and Private Standards for Food Safety and Quality: International Trade Implications. Estey Centre Journal of International Law and Trade Policy, 11(1), 136-152.

IFPRI. (2005). The future of small farms. Proceedings of a research workshop. Washington, DC: International Food Policy Research Institute.

International Certification and Auditing Company Limited (CTR). (2007). Turkey. http://ctr.com.tr

Jaffee, S. (2003). From Challenge to Opportunity: Transforming Kenya's Fresh Vegetable Trade in the Context of Emerging Food Safety and other Standards in Europe, World Bank, Agriculture and Rural Development Discussion Paper No. 2. Washington, D.C.

Jaffee, S., Henson, S. \& Rios, L. D. (2011). Making the grade: Smallholder Farmers, Emerging Standards, and Development Assistance Programs in Africa: A Research Program Synthesis. Economic and sector work Report No. 62324-AFR, World Bank.

Killick, T., Kydd, J. \& Poulton, C. (2000). Agricultural Liberalization, Commercialization and the Market Access Problem in the Rural Poor and the Wider Economy: The Problem of Market Access. International Fund for Agricultural Development, Rome.

Kleemann, L. (2011). Organic Pineapple Farming in Ghana - A Good Choice for Smallholders? Working Paper No. 1671 Kiel Institute for the World Economy.

Kuwornu, J. K. M., Kuiper, W. E. \& Pennings, J. M. E. (2009). Agency Problem and Hedging in Agri-Food Chains: Model and Application. Journal of Marketing Channels, 16, 265-289.

Laforce, V. C. (2010). Between the requirements of regulations and standards in food safety: challenges and opportunities for developing countries' exports of tropical fruits to the European Union. 
Paper prepared for the Conference on Regulation in the Age of Crisis, Third Biennal Conference of the European Consortium of Political Research's Standing Group on Regulatory Governance, June 17-19 2010, UCD Dublin.

Ministry of Food and Agriculture, Ghana. (2010). Medium Term Agricultural Sector Investment Plan (METASIP) (2010) 2011-2015.

Market Oriented Agricultural Programme. (MOAP). Progress report January to December 2009.

Minot, N. \& Ngigi, M. (2004). Are Horticultural Exports a Replicable Success Story? Evidence from Kenya and Cote D Ivoire LPTD/MTID discussion paper, IFPRI; Washington, D.C. IFPRI.

Millennium Project Task Force on Hunger. (2004). Halving Hunger by 2015: A Framework for Action. Interim Report. Millennium Project. New York.

Murithi, B., Mbunu, J. \&Ngigi, M. (2008). Constraints and Determinants of Compliance with EureGap Standards: A Case of Smallholder French Bean Exporters in Kirinyaga District.

National Department of Agriculture Directorate: Marketing. (2002). The Integrated Food Security Strategy for South Africa. Pretoria.

Natural Resources Institute. (2010). Ghana Export Horticulture Cluster Strategic Profile Study. Study prepared for the World Bank Sustainable Development Network (WB-SDN) Africa Region, Agriculture and Rural Development (AFTAR), The Republic of Ghana Ministry of Food and Agriculture, and European Union All ACP Agricultural Commodities Programme (EU-AAACP). Draft of January 27, 2010.

Organization for Economic Co-Operation and Development (OECD). (2006a). Private standards and the Shaping of the Agro-food System, Paris.

Organization for Economic Co-Operation and Development (OECD). (2006b). Private Standard Schemes And Developing Country Access To Global Value Chains: Challenges And Opportunities Emerging From Four Case Studies Working Party On Agricultural Policies And Markets AGR/CA/APM(2006)20, 27-Sep-2006.

Okello, J. J., Narod, C. \& Roy, D. (2009). Why market institutions disfavor smallholder farmers' compliance with international food safety standards: Evidence from Kenya, Zambia and Ethiopia. Contributed Paper prepared for presentation at the International Association of Agricultural Economists Conference, Beijing, China, August 16-22, 2009.

Orden, D., Lofgren, H. \& Gabre-Madhin, E. (2004). Trading Up: How International Trade and Efficient Domestic Markets Can Contribute to African Development. Brief prepared for the conference on Assuring Food and Nutrition Security in Africa by 2020: Prioritizing Actions, Strengthening Actors, and Facilitating Partnerships, April 1-3, 2004, Kampala,Uganda.4pp.

Pay, E. (2009). The market for organic and fair-trade mangoes and pineapples. Study prepared in the framework of FAO project GCP/RAF/404/GER Increasing incomes and food security of small farmers in West and Central Africa through exports of organic and fair-trade tropical products. Food and Agriculture Organization of the United Nations (FAO), Trade and Markets Division, Rome.

Raynolds, L. T. \& Ngcwangu, S. U. (2010). Fair Trade Rooibos tea: Connecting South African producers and American consumer markets. Geoforum, 41(1), 74-83.

Revised Ghana Food Safety Action Plan. (2007). Republic of Ghana Ministry of Food and Agriculture Food safety Task Force, World Bank, Africa Agriculture and Rural Development (AFTAR), final draft, November.

Richard, C., Yudin, M. C. \& Keith, R. S. (2008). European Food Safety Certification - The GlobalGAP Standard and its Accredited Certification Program, FSHN 0801, The Institute of Food and Agricultural Sciences (IFAS), University of Florida.

Sefa-Dedeh, S. (2005). Ghana Private-Public Partnership Food Industry Development Program Final Report for USAID Associate Cooperative Agreement No. 641-A-00-03-0003.

Sexsmith, K. \& Potts, J. (2009). Voluntary sustainability standards and economic rents: The economic impacts of voluntary sustainability standards along the coffee, fisheries and forestry value chain, IISD: International Institute for Sustainable Development, Winnipeg, Manitoba.

Van-Roekel, J., Willems, S. \& Boselie, D. M. (2002). Agri-Supply Chain Management: To Stimulate Cross Border Trade in Developing Countries and Emerging Economies. World Bank Paper Cross Border Agri Supply Chain Management, 28.

Wechter, K. \& Grethe, H. G. (2006). The adoption of the Eurepgap standards by mango exporters in Piura, Peru, Australia. University of Berlin Germany, Berlin. 